\title{
Brand Equity and Market-based Assets of Professional Service Firms
}

\author{
Byron Sharp \\ Journal of Professional Services Marketing, (USA), Vol.13 No.1, p.3-13

\begin{abstract}
The concept of brand equity has received most attention in the context of fast-moving-consumer-goods marketing yet the concept is just as, if not more, important to professional services marketers. This paper explains the distinct nature of market-based assets, such as brand equity, in professional service industries.
\end{abstract}

\section{THE VALUE OF BRAND EQUITY}

To a large extent interest in brand equity has been confined to the fast-movingconsumer-goods context. Indeed, when one thinks brand it is names such as CocaCola, Marlboro, and Dove, which come to mind, rather than great service brand names such as Young \& Rubicam or Dun \& Bradstreet. But professional service companies can also own market-based intangible assets and they are likely to make up a greater proportion of the firm's asset base than that of manufacturing firms. This paper sets out to discuss the unique nature of such assets in this context.

The concept of brand equity has been receiving considerable academic and practitioner attention of late. The rise in interest can be traced to a series of takeovers and valuations during the late 1980s which recognised the staggering values which brand names can reach. In 1987 Grand Metropolitan announced that half a billion

Byron Sharp is the Director (Research) of the Marketing Science Centre at the University of South Australia. He has published in Australian, European and North American journals on topic of brand strategy.

Address all correspondence to: Byron Sharp, MSC, Elton Mayo School of Management, University of South Australia, S.A. 5000, Australia. 
dollars of the sum paid to acquire Heublein was attributable to the asset of the brand Smirnoff. In 1988, Nestle paid two and a half billion pounds, six times the value of the net tangible assets of the British company Rowntree, the differential being attributed to the value of Rowntree's intangible brand assets. Valuations of brand holdings quickly followed as companies attempted to acknowledge the premiums they had paid in acquisitions or they attempted to fend off takeover bids by acknowledging brand values on their balance sheets. In Australia, Elders IXL's 1990 Annual Report included valuations of the brand names owned by the Carlton group (including Fosters) at between $\mathrm{A} \$ 1.05$ and $\mathrm{A} \$ 1.2$ billion.

In the United States different laws regarding the inclusion of intangible assets in financial statements may have made similar public valuations more difficult but they have not stopped managers recognising the value of brand equity. For example, Hamish Maxwell, Chairman of Phillip Morris explained that brands were the main reason behind their $\$ 18$ billion purchase of Kraft and General Foods:

To be sure, both companies brought with them outstanding management talent. Their manufacturing and distribution capabilities were impressive. But it was their brands - the Krafts, the Jell-Os, Maxwell House and Oscar Mayer that made the deals so compelling (Maxwell 1990).

Such activity in the financial world stimulated renewed academic and practitioner interest in brands and their strategic worth as well as their financial worth. There have been a number of international conferences, journals, and book launches, and brand equity was ranked at the top of a survey by the Marketing Science Institute to determine members' opinions on what were the most pressing questions in need of research (Aaker 1991).

\section{THE IMPORTANCE OF MARKET-BASED ASSETS FOR PROFESSIONAL SERVICES}

Any organisation can be considered as a distinct grouping of tangible assets, which are typically valued and recorded in financial statements, and intangible assets which typically are not recorded in financial statements. These intangible assets comprise assets which are internal to the organisation (eg skills, experience, motivation, patents) and market-based assets such as customer loyalty, brand/corporate image, customer 
awareness, secured distribution, and relationships with customers/distributors. Intangible assets make up the overwhelming majority of the assets of professional service firms which, unlike manufacturing firms, are unlikely to hold significant amounts of tangible assets such as machinery, inventories, or property.

Such market-based assets are predominantly discussed in the marketing literature under the term brand equity; a term which is not entirely appropriate in the professional service context. The vast amount of literature which uses the terms product and brand interchangeably has given the word brand strong consumer product connotations. It also makes less sense to discuss a professional service firm's market-based assets as relating to specific brands. Professional service companies seldom offer distinct bundles of service in the way that consumer goods companies do. Nor is the brand equity of the firm always directly tied to the brand or company name, but rather may reside partially in names of individual service providers (ie people) within the company. For these reasons this paper uses the more general and encompassing term marketbased assets to describe all of a firm's intangible assets which are distinct from internal intangible assets and skills.

\section{Market-based Intangible Assets}

...for many of today's corporations their most valuable assets are not tangible assets but intangible assets, especially brands (Penrose \& Moorhouse 1989)

Sustainable competitive advantage results from the possession of relevant capability differentials. The feedstock of these differentials is intangible resources (Hall 1992).

There is an increasing emphasis being placed in the marketing and strategic management literature on the role of intangible assets in underlying competitive advantage (see Aaker 1991, Amit and Schoemaker 1993, Hall 1992, Itami and Roehl 1987, Peteraf 1993). A 1989 survey asked 248 Californian managers what they felt the sustainable competitive advantage (SCA) of their businesses was. The intangible asset of "reputation for quality" was the most commonly cited SCA (Aaker 1989). In two surveys of United Kingdom companies, in 1987 and 1990, chief executive officers consistently reported that the market-based assets of "company reputation" and "product reputation" were the most important of all intangible assets in contributing to company success (Hall 1992). The same executives also listed these assets as those which would take longest to replace from scratch. This is recognition of the importance of understanding how to maintain such assets if a business is to remain competitive. 
In spite of this appreciation by management executives, scholarly attention is a relatively recent event. To a large degree the extant marketing literature still displays a strong neo-classical economic view of the way in which markets work. Though marketing theory has certainly progressed beyond the view that market share is purely a function of product and price ${ }^{1}$, to include the effects of other variables such as advertising, personal selling and distribution, market exchanges still seem to be viewed as discrete events (Dwyer, Schurr and Oh 1987, see also Day and Wensley 1983). The development of marketing theory has generally paid little attention to the effects of previous trading activity, thus ignoring the concept of market-based assets and how they mediate the effects of current marketing effort on sales performance. In reality it is not always the best product or service that wins, nor is it always the best overall marketing mix (4Ps); current performance is very much driven by previous performance and prior investments in marketing effort (including product/service quality). This conceptualisation of "how markets work" can be shown diagramatically:

\section{How Markets Work}

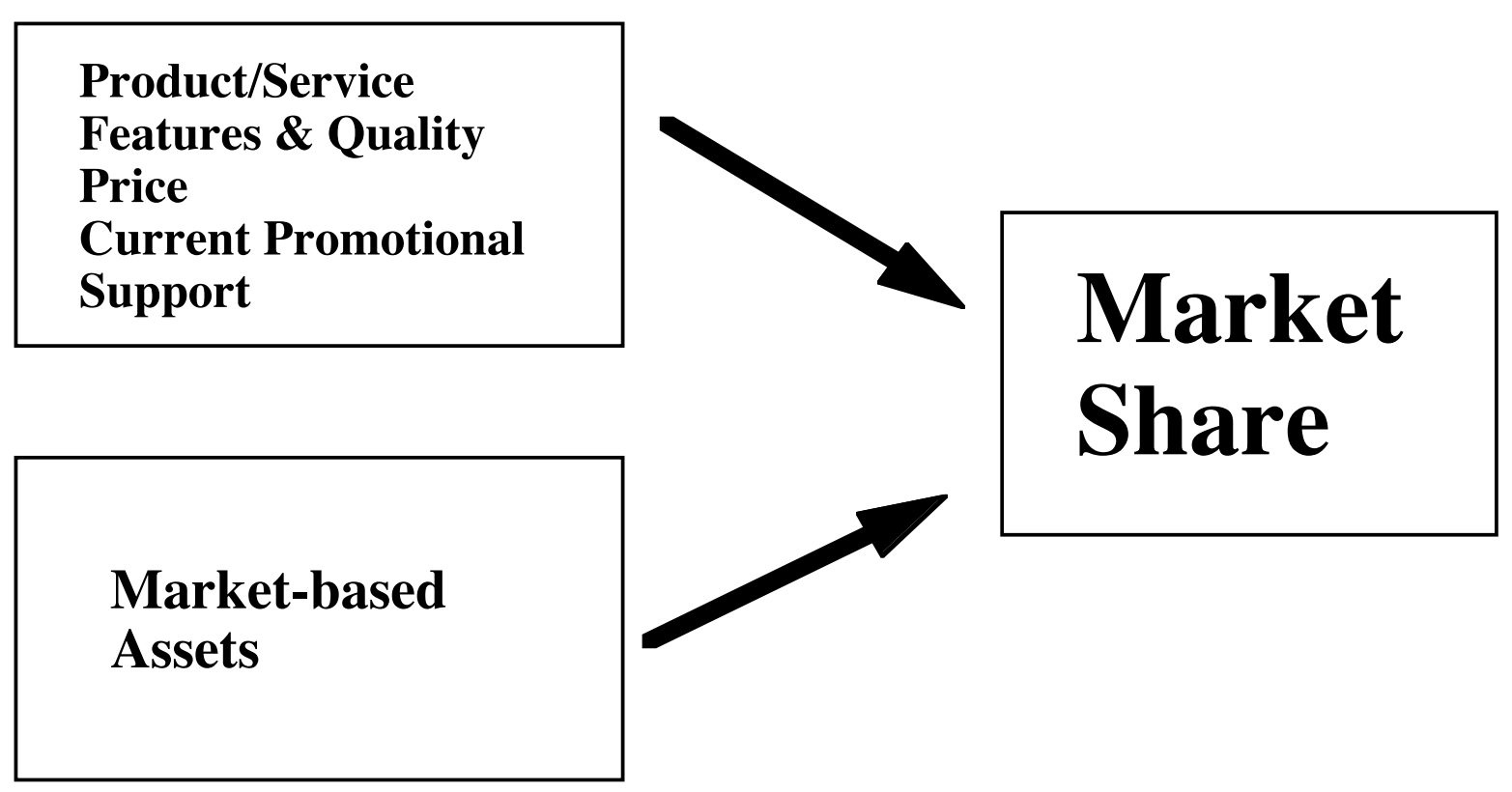

\footnotetext{
1 The services literature has shown an even greater preoccupation with just one variable's impact on marketplace performance, that is, service quality.
} 


\section{THE MARKET-BASED ASSETS OF PROFESSIONAL SERVICE FIRMS}

There are three distinct differences about professional services marketing which are relevant to the issue of market-based assets, their nature, and the way they operate.

Firstly, there is the issue of importance. Since professional services firms seldom hold any substantial tangible assets, and considering that market-based assets are reported as the most important of intangible assets, then it would appear that marketbased assets are the most important assets of such firms.

Secondly, professional services marketing places different emphasis on certain marketing mix elements than does product or consumer service marketing. Price is seldom so clearly displayed, distribution doesn't take place through intermediaries in the same way, and many types of impersonal communication, such as advertising, are restricted by industry codes or customer expectations.

Thirdly, there are fundamental differences between professional services and products which affect the way consumers evaluate such offerings. Professional services are high on experience and credence values in comparison to products which are more tangible. With professional services it can be very difficult for consumers to assess just what they are going to get, in regard to service features and service quality, prior to consumption. For example custom computer software writing services are of unknown perceived quality until they have actually been supplied. In some cases where professional services have high credence values, for example education services or legal advice, even after consumption clients may find it difficult to assess quality.

\begin{tabular}{|c|c|c|}
\hline $\begin{array}{c}\text { Professional } \\
\text { Services }\end{array}$ & $\begin{array}{l}\text { Consumer } \\
\text { Services }\end{array}$ & Products \\
\hline $\begin{array}{l}\text { High on } \\
\text { experience values } \\
\text { High on credence } \\
\text { values } \\
\text { Difficult for } \\
\text { consumers to } \\
\text { assess quality } \\
\text { even after } \\
\text { consumption }\end{array}$ & $\begin{array}{l}\text { High on } \\
\text { experience values } \\
\text { Difficult for } \\
\text { consumers to } \\
\text { assess quality and } \\
\text { features until after } \\
\text { consumption }\end{array}$ & $\begin{array}{l}\text { High Tangibility } \\
\text { Consumers can } \\
\text { assess quality and } \\
\text { features }\end{array}$ \\
\hline
\end{tabular}


These differences mean market-based assets perform different roles and vary in importance in professional service industries compared to product industries. The rest of this article examines individual market-based assets in a professional service context.

\section{Company/ Brand Awareness}

Awareness is an important asset which results from a firm's marketing communications activities and is also a reflection of its market share (customers are likely to have highest awareness of the company they used last). While awareness levels are caused by sales levels, awareness also has a positive impact on sales levels. Thus we have a "virtuous circle".

\section{Awareness}

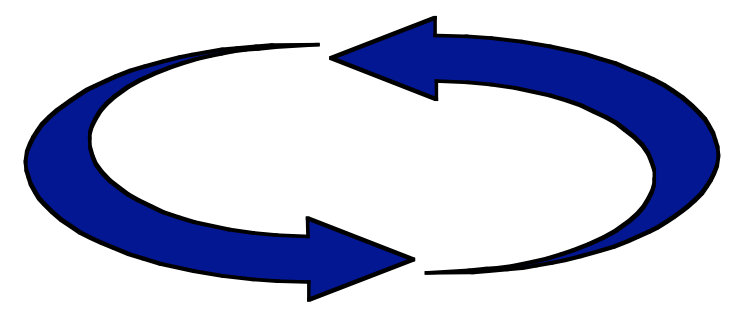

\section{Sales}

Like other market-based assets brand awareness is based, to a large degree, on the age of the firm. So it acts as a barrier to entry against newer, younger firms who find it difficult to quickly gain similar awareness levels of those held by the existing firms. This is particularly true where mass communication is not feasible, as is the case in many professional service industries. Indeed the marketing communications activity of new entrants often has the effect of lifting the brand awareness, and sales, of existing firms due to brand ambiguity where the communication attempts of new firms are mistaken by customers as being for existing firms/ brands. Brand ambiguity is encouraged by high levels of brand awareness for existing firms. Brand awareness provides its owners with what have been described as incumbency advantages (Kay 1993).

Awareness has a positive effect on sales through a variety of mechanisms. Firstly, it has a positive influence on perceived quality and preference (Baker et al 1986, Zajonc 1980). It is thought that consumers reason, that if they have heard of a company, then that company must have many clients and be performing well. It is reasoned that this could only be the case if other customers were satisfied with its performance, and hence a company with a known name is thought to be more likely to give better quality service than a company with an unknown name. Awareness is also closely associated with familiarity and it has been noted that consumers feel safer with things they are familiar with, thus awareness reduces risk for consumers. This dislike for things which are unknown or foreign is an accepted part of human nature. Psychologists have for 
long noted that when people are asked to describe familiarity they tend to use "warm" positive expressions (Titchener 1912).

A second major reason why awareness has a positive impact on sales is the utilisation of choice heuristics by customers. In an effort to minimise search costs and cognitive effort consumers may adopt decision shortcuts, such as choosing the brand they have heard of or remember first (Bettman et al 1991, Deshpande et al 1982, Dashpande and Hoyer 1983). This phenomena has been thought to mainly apply to low involvement decision making for products such as toothpaste or potato chips, however, such decision tactics may also be adopted for decisions involving much more complicated "products" such as professional services. Professional services are normally classed as high involvement "goods" because they are of a complicated nature and consumers face costly consequences for a wrong decision (consider the potential consequences of the wrong choice of lawyer, doctor, or taxation advisor). Therefore it has often been assumed that heuristics would not play such a role in consumer choice behaviour for professional services, instead, it is thought, consumers would engage in extended search before making choices. However, this reasoning ignores the nature of

professional services, specifically that they are high on experience and credence values. Consumers find it very difficult to find information which would allow them to fully assess competing offerings and consumers often feel "unqualified" to fully assess the information they may be able to obtain. Thus, consumers may very well make use of heuristics such as choosing the first provider that comes to mind - the one with highest brand awareness. Brand awareness can play the same important role as a market-based asset for professional services as it does for low involvement products but, as illustrated, for different reasons.

\section{Brand Image}

Brand image, or by another name - company/brand reputation, is rapidly being seen as not just something of concern to public relations and advertising people. In an "overcommunicated" society, where product/service releases also occur at an ever more frantic rate, and are copied by competitors at a similar rate, reputation increases in importance as a strategic asset which is less easily duplicated by competitors.

Competitors' efforts to gain similar brand images run the risk of brand ambiguity benefiting the existing "owner" of the position or of being rejected by consumers (Ries and Trout 1981). A clear brand image also improves the effectiveness of a company's communication efforts, allowing it to stand out from the clutter.

Just what the brand or company name means to the consumer obviously affects buying behaviour. It can add value to the offering, as clearly seen with prestigious names, and it can reduce risk for buyers. A brand such as McKinseys has a brand 
image strong on quality certification, thereby reducing the risk for clients who wish to employ a consultant for a major project, but the brand image also provides symbolic benefits for clients - many companies believe that having a prestigious adviser enhances their own reputation (Kay 1993).

A brand image for quality is particularly important to professional service providers because of the difficulty consumers have in assessing quality even after consumption.

\section{Relationships with customers/ Existing customer franchise}

Probably the greatest guarantee of future clientele for a professional service provider is the existence of current clients. While such a statement may sound applicable to almost any industry, professional services are marked by significant switching costs for customers. The provision of professional services often involves considerable investment in getting to know the client's needs and circumstances. For instance, as they undertake work for a client, a market researcher develops a greater understanding of the client's business objectives, competitive pressures and, of course, the behaviour of the client's customers. Indeed until a market researcher has developed this knowledge they may be of very little use to the client at all. The client gains from this investment in increased quality (and speed) of the service and the producer gains from the clients' recognition that to change supplier would mean losing the benefits of this investment. It is for this reason that accepted norms of long-term, sometime contractual, relationships are not uncommon throughout various professional service industries.

Switching costs are also high where there is difficulty in assessing service quality prior to consumption. A customer's existing supplier is something of a known quantity whereas other suppliers are of unknown quality. Likewise, it can be very difficult to assess the value of any potential cost savings in switching suppliers, as without standardised services, price comparisons are difficult. If the risk of choosing a poor quality provider is high, which is often the case for professional services, then so long as the existing provider is performing, at least adequately, many customers will feel reluctant to stray. Claims of service quality on behalf of competing providers do little to prevent this as customers expect claims made by service providers themselves to always be exaggerated. If customers do desire to switch providers, they are most likely to do so based on the recommendation of customers of other suppliers, again highlighting the value of having an existing, and satisfied, client base.

Other than retaining and gaining clients the other source of revenue increase is to gain more sales from existing clients. Professional services by their very nature tend to be multi-faceted with plenty of opportunity to on-sell from one service to another. Existing relationships with customers provide the basis for on-selling. Very often the 
involvement with one person within a client organisation allows the introduction to other potential buyers within that organisation. Selling to people who already buy from you is significantly easier than selling to those who do not.

\section{CONCLUSION}

Market-based assets, including brand equity, certainly do exist in professional service industries and they play an important, if not vital, role in the sustainable competitive advantages of professional service organisations. Market-based assets for professional service firms are derived from different sources due to the differences in professional service consumer behaviour. Marketers need to appreciate these differences if they are to effectively build these assets.

For product marketers, brand equity occurs primarily through consumers seeking to minimalise cognitive effort (as in the case of supermarket goods) or though the addition of symbolic value (as in the case of fashion items). Professional service brand equity can also occur for these reasons but, because of the distinct nature of professional services, brand equity is more likely to occur because consumers need a way to reduce risk and to assess quality. In product markets the level of secured distribution, particularly shelf space, is an important market-based asset. This is not so much the case for professional services which seldom rely to the same degree on intermediaries. This is not to say, however, that relationships do not constitute an important marketbased asset. Whereas for the product marketer relationship quality with intermediaries plays an important role in the firm's success, professional service providers form business relationships directly with clients.

These market-based intangible assets require the investment of considerable resources and are built up over time. Professional service firms strive over time to enhance the value of their companies and ensure future revenue flows through the building and maintenance of such assets. To date the professional service marketing literature has tended to focus on issues involved in encouraging a marketing orientation in professional service firms and in how to ensure service quality. In the future explicit attention will need to be paid to the role of marketing in creating strategic market-based assets and how these assets underpin sustainable competitive advantage ${ }^{2}$. Attention

\footnotetext{
${ }^{2}$ Bharadwj, Varadarajan and Fahy cite two recent reviews of the literature on all types of services marketing (Fisk, Brown and Bitner 1993, Swartz, Bowen and Brown 1992 ) which allude to the dearth of strategic emphasis in exant literature.
} 
needs, also, to be paid to the management of these assets. This article, in an attempt to highlight the importance of, and stimulate interest in, these assets for professional service firms, has attempted to briefly explain what type of market-based asset can exist and why. 


\section{REFERENCES}

Aaker, David A. (1989) "Managing Assets and Skills: The Key To a Sustainable Competitive Advantage" California Management Review, Winter, p.91-106.

Aaker, David A. (1991) "Managing Brand Equity", The Free Press: New York.

Amit, Raphael, Shoemaker, Paul J.H. (1993) "Strategic Assets and Organizational Rent", Strategic Management Journal, Vol.14 p.33-46.

Baker, W., Hutchinson, W., Moore, D., Nedungadi, P. (1986) "Brand Familiarity and Advertising Effects on the Evoked Set and Brand Preferences", Advances in Consumer Research, Vol.13 p.637-642.

Bettman, James R., Johnson, Eric J., Payne, John W. (1991) "Consumer Decision Making" in Handbook of Consumer Research (Eds. Robertson, T.S., Kassarjian, H.H), Prentice Hall: New Jersey, p.50-84.

Bharadwaj, Sundar G., Varadarajan, P. Rajan, Fahey, John (1993) "Sustainable Competitive Advantage in Service Industries: A Conceptual Model and Research Propositions", Journal of Marketing, Vol.57 (October) p.83-99.

Day, George S., Wensley, Robin (1983) "Marketing Theory with a Strategic Orientation", Journal of Marketing, Vol.47 (Fall), p.79-89.

Deshpande, Rohit, Hoyer, Wayne D. (1983) "Consumer Decision Making Strategies, Cognitive Effort and Perceived Risk", in AMA Educators Conference Proceedings (Ed. Murphy, P.E.), American Marketing Association: Chicago.

Deshpande, Rohit, Hoyer, Wayne, Jefferies, Scot (1982) "The importance of choice tactics" in Marketing Theory: a philosophy of science perspective (Ed.s Bush.R.F. and Hunt, S.D.), American Marketing Association: Chicago, p.155-158.

Dwyer, Robert F., Schurr, Paul H., Oh, Sejo (1987) "Developing Buyer-Seller Relationships", Journal of Marketing, Vol.51 (April) p.11-27. 
Fisk, Raymond P., Brown, Stephen W., Bitner, Mary Jo (1993) "Tracking the Evolution of the Services Marketing Literature" Journal of Retailing, Vol.69 (Spring) p.61-103.

Hall, Richard (1992) "The Strategic Analysis of Intangible Resources", Strategic Management Journal, Vol.13 p.135-144.

Itami, Hiroyuki, Roehl, Thomas W. (1987) "Mobilizing Invisable Assets", Harvard University Press: Cambridge, Mass.

Kay, John (1993) "Foundations of Corporate Success", Oxford University Press: Oxford.

Maxwell, Hamish (1990) "The \$18 billion brand man speaks", Marketing Magazine (Australia), August p.20-24

Penrose, Noel, Moorhouse, Martin (1989) "The Valuation of Brands", Marketing Intelligence and Planning, Vol.7 No.11/12 p.30-33.

Peteraf, Margaret A. (1993) "The Cornerstone of Competitive Advantage: A Resource-Based View", Strategic Management Journal, Vol.14 p.179-191.

Ries, Al, Trout, Jack (1981) "Positioning: the battle for your mind", McGraw-Hill: New York.

Swartz, Tersa A., Bowen, David E., Brown, Stephen W. (1992) "Fifteen Years After Breaking Free: Services Then, Now and Beyond" in Advances in Services Marketing and Management: Research and Practice, Vol.1, (Ed.s Swartz, T.A., Bowen, D.E., Brown, S.W.), JAI Press: Greenwich, CT.

Tichener, Edward B. (1912) "A Textbook of Psychology", Macmillian: New York.

Zajonc, Robert B. (1980) "Feeling and Thinking: Preferences Need No Inferences", American Psychologist, p.151-175. 